\title{
On Complete Carbon Emission of China's Industries Based on Input-Output Analysis
}

\author{
Changcai QIN \\ School of Economics and Business, Yantai University, Yantai 264005, China \\ E-mail: qinchangcai@126.com
}

\author{
Shulin LIU \\ School of International Trade and Economics, University of International Business and Economics, \\ Beijing 100029, China \\ E-mail: slliu@uibe.edu.cn
}

\begin{abstract}
This article establishes a useful analytical framework for complete carbon emission of the industries in China and then makes comparison on carbon emission among these industries based on the latest data derived from China's Input-Output Table and Energy Statistics in 2007. It is found that some industries are "invisible high-carbon" sectors by the definitions of directly-embodied coefficient and perfectly-embodied coefficient and that others have made contributions to carbon leakage by measure of importing and exporting carbon emission volume. Finally, this article provides suggestions to industrial strategies, trade policies and the comprehensive economic management policy in order to effectively achieve energy conservation and emission reduction.
\end{abstract}

Keywords input-output analysis; directly-embodied coefficient; perfectly-embodied coefficient

\section{Introduction}

It is well known that global warming has seriously threatened human's survival environment. This is ascribable to the carbon dioxide as a leading component in greenhouse gas. Therefore, the issue concerning reduction of greenhouse gas, especially of carbon dioxide, has attracted world-wide attention. In June 1992, the United Nations' Conference on Environment and Development approved "United Nations Framework Convention on Climate Change", appealing to ultimately limit the greenhouse atmosphere concentration at a reasonable level so as to maintain the world's sustainable development. Besides, the Kyoto protocol signed in 1997 further regulated specific objectives for developed countries as to how they implement carbon emission reduction strategies at the initial stage. China has grown to be the biggest developing country in the world, which is consistent with its numerous energy consumption and carbon emission accordingly. For instance, in 2007, China carbon dioxide discharge reached 6.72 billion tons which occupied a percentage of $24.3 \%$ in the world total amount and exceeded the record made by the US, and thereby become No.1. At the United Nations Climate Change Summit

Received December 11, 2013, accepted December 18, 2013

Supported by the Social Science Planning Fund - Youth Project in Shandong Province (Grant No. 13DJJJ22) 
held in 2009, the Chinese government claimed that by 2020 carbon dioxide emissions per Gross Domestic Product would be reduced by $40 \%$ to $45 \%$ compared with $2005^{[1]}$.

Realization of the overall target of emission reduction largely depends on specific industrial policies and trade policies that are supported by scientific theories and empirical analysis. In general, carbon emission mainly originates from consumption of fossil fuel, which is further divided into direct and indirect consumption. The so-called direct consumption comes from energy consumed during direct manufacturing process of final output, while the indirect one refers to energy consumed in the process of producing intermediate product. The two types of energy consumption are accompanied by carbon discharge, which leads to concepts of direct and indirect carbon emissions. The total sum of direct and indirect carbon emissions constitutes a complete carbon emission for any end products made by all industrial sectors. As a usual rule, input-output analysis is suitable for making calculation of the complete carbon emissions.

Many literatures have analyzed carbon embodied in goods and services via input-output analysis, including [2] aiming for Japan, [3] and [4] aiming for Brazil, [5] aiming for Spain, [6] aiming for Australia, [7] aiming for Italy, [8] aiming for India. Meanwhile, in China some researchers have also concentrated attention on carbon emission individually from the angle of final consumption and embodied discharge of China in 2002 by [9], from the final demand for energy consumption in international business in 2002 by [10, 11], and from the embodied discharge of imports and exports by [12]. It should be noted that [13] examined the carbon emission between China and the US separately. Furthermore, [14] established regional carbon structural analysis model, and [15] made a comparative study between China and some developed countries from OECD by using data concerning industrial sectors and G7 as well.

The above-mentioned literature mainly focus on embodied carbon resulting from global trade and at the same time emphasize carbon release between nations in the world with the latest data in 2005. This article, however, places emphasis on comparison of carbon emission characteristics between various industries, followed by suggestions on emission reduction with the latest data deriving from the Input-Output Table of 2007.

The paper is structured as follows. Section 2 sets up an analytical framework of industrial complete-carbon emission after defining perfectly-embodied carbon coefficient, and then makes some explanations on applicable variables and data. Calculation results and empirical analysis are shown in Section 3. Finally, a conclusion and recommended suggestions are made in Section 4 .

\section{Methodology}

\subsection{Analytical framework concerning complete carbon emission of the industries}

Input-output analysis can comprehensively reflects the interdependence of internal sectors in an economic system. The basic formula is described as follows

$$
x=(I-A)^{-1} Y
$$

where $X=\left(X_{1}, X_{2}, \cdots, X_{n}\right)^{\mathrm{T}}$ is the vector of total output, $Y=(E, M, c o n, I)$ is the vector of final demand, $E=\left(E_{1}, E_{2}, \cdots, E_{n}\right)^{\mathrm{T}}$ is the export vector, $M=\left(M_{1}, M_{2}, \cdots, M_{n}\right)^{\mathrm{T}}$ is the import vector, $c o n=\left(\operatorname{con}_{1}, \operatorname{con}_{2}, \cdots, \text { con }_{n}\right)^{\mathrm{T}}$ is the consumption vector, $I=\left(I_{1}, I_{2}, \cdots, I_{n}\right)^{\mathrm{T}}$ 
is the investment vector, $(I-A)^{-1}=\left(b_{i j}\right)_{n \times n}$ is the Leontief inverse matrix, and $b_{i j}$ means the consumption of sector $i$ 's end product per unit on sector $j$ 's final product.

Next, we define an important concept called direct carbon emission coefficient (abbreviated as DCEC) of sector $k$ as below:

$$
d_{k}=\frac{C_{k}}{x_{k}}=\frac{\sum \delta_{i} \gamma_{i} q_{i k}}{x_{k}}, \quad k=1,2, \cdots, n
$$

where $q_{i k}$ refers to energy sector $i$ 's direct energy demand of sector $k$ in physical units, $\gamma_{i}$ the coefficient used to convert the $i$ th kind of energy into BiaoMei, $\delta_{i}$ the carbon emission coefficient of every energy, $C_{k}$ the gross carbon emissions of sector $k$, and $x_{k}$ the gross output of sector $k$, $d=\left(d_{1}, d_{2}, \cdots, d_{n}\right)$ the vector of direct carbon emission coefficients.

Based on direct emission coefficient $d_{k}$ and the meaning of $b_{i j}$, we define the second essential concept called the total carbon emission coefficient (abbreviated as TCEC) of sector $k$ as shown below:

$$
\lambda_{k}=\sum d_{j} b_{j k}
$$

where $\lambda=\left(\lambda_{1}, \lambda_{2}, \cdots, \lambda_{n}\right)=d(I-A)^{-1}$ is the vector of total carbon emission coefficients. As a result, the gross carbon emission is computed as:

$$
c=\lambda Y=(\lambda E, \lambda M, \lambda C o n, \lambda I)
$$

where $\lambda E=\sum \lambda_{i} E_{i}$ is the gross carbon emission of the exporting sectors, $\lambda M=\sum \lambda_{i} M_{i}$ the gross carbon emission of the importing sectors, $\lambda$ Con $=\sum \lambda_{i}$ Con $_{i}$ the gross carbon emission of the consumption sectors, and $\lambda I=\sum \lambda_{i} I_{i}$ the gross carbon emission of the investment sectors. Thus, the net export carbon emission is computed as $N X-C=\lambda E-\lambda M$.

\subsection{Data source of the Variables}

According to the definitions of the above variables, they are divided into four levels such that the variables in the lower levels are computed from the variables in the higher levels as

\begin{tabular}{|c|c|c|c|c|}
\hline \multicolumn{4}{|c|}{ Variable } & \multirow{2}{*}{ Data source } \\
\hline Grade 1 & Grade 2 & Grade 3 & Grade 4 & \\
\hline \multirow{5}{*}{$\lambda_{i}$} & \multirow{4}{*}{$d_{j}$} & \multirow{3}{*}{$C_{k}$} & $q_{i k}$ & China's Input-Output Table $(2007)^{1}$ \\
\hline & & & $\gamma_{i}$ & China's Input-Output Table (2007) \\
\hline & & & $\delta_{i}$ & IPCC (2006) et al. ${ }^{2}$ \\
\hline & & $X_{k}$ & & China's Input-Output Table (2007) \\
\hline & $b_{j k}$ & $A$ & & China's Input-Output Table (2007) \\
\hline$E_{i}, M_{i}, \operatorname{con}_{i}, I$ & & & & China's Input-Output Table (2007) \\
\hline
\end{tabular}
shown in Table 1. In Table 1, we also list the data sources of these variables ${ }^{[16-17]}$.

Table 1 Variables list

\footnotetext{
${ }^{1}$ China's Input-Output Table (2007) is quoted from website: http://www.iochina.org.cn/.

${ }^{2}$ The United Nations Intergovernmental Panel on Climate Change (IPCC) is an intergovernmental body established in 1988 by the World Meteorological Organization (WMO) and the United Nations Environment Programme (UNEP) jointly. Its main task is to assess the current state of scientific knowledge on climate change, the potential impact of climate change on society and economics, and possible countermeasures for adapting to and mitigating climate change. Up to 2006, IPCC has released four reports.
} 
Since the carbon emission of each industry equals the consumption of BiaoMei multiplied by carbon emission coefficient and BiaoMei consumption is calculated based on average low calorific value, nine kinds of resources are chosen including coal, coke, crude oil, petrol, kerosene, diesel oil, fuel oil, natural gas and electricity when measuring energy consumed by each sector. The data of $\gamma_{i}$ and $q_{i k}$ comes from China's Energy Statistics Yearbook (2007). The relevant nine $\gamma_{i} \mathrm{~s}$ and $\delta_{i}$ s are shown in Table 2 .

Table 2 Coefficients in terms of coal for the nine kinds of energy resources

\begin{tabular}{clllll}
\hline Coefficient & Coal & coke & Crude oil & Petrol & Kerosene \\
\hline$\gamma_{i}$ & 0.7143 & 0.9714 & 1.4286 & 1.4714 & 1.4714 \\
& $(\mathrm{~kg} \mathrm{sc} / \mathrm{kg})$ & $(\mathrm{kg} \mathrm{sc} / \mathrm{kg})$ & $(\mathrm{kg} \mathrm{sc} / \mathrm{kg})$ & $(\mathrm{kg} \mathrm{sc} / \mathrm{kg})$ & $(\mathrm{kg} \mathrm{sc} / \mathrm{kg})$ \\
$\delta_{i}$ (ton-coal$\left./ \mathrm{tsc}\right)$ & 0.682 & 0.765 & 0.676 & 0.620 & 0.616 \\
\hline \hline Coefficient & Diesel oil & Fuel oil & Natural gas & Electricity & \\
\hline \multirow{2}{*}{$\gamma_{i}$} & 1.4571 & 1.4286 & 1.3300 & 0.1229 & \\
& $(\mathrm{~kg} \mathrm{sc} / \mathrm{kg})$ & $(\mathrm{kg} \mathrm{sc} / \mathrm{kg})$ & $\left(\mathrm{kg} \mathrm{sc} / \mathrm{m}^{3}\right)$ & $(\mathrm{sc} / \mathrm{kwh})$ & \\
$\delta_{i}$ (ton-coal/tsc) & 0.657 & 0.717 & 0.523 & 1.814 & \\
\hline
\end{tabular}

tsc means "ton of standard coal equivalent"; sc refers "standard coal".

There are forty-two sectors'data in Chinese Input-Output Table (2007). Due to less energy consumption and carbon emissions by the tertiary industry, all sectors within the tertiary industry are merged into only five sectors. In addition, several sectors in the secondary industry are also merged (see Table 3). Thus, we will deal with thirty sectors and for convenience they are numbered (see Table 4).

Table 3 Departments before and after merging

\begin{tabular}{lll}
\hline Industry & Departments before merging & Departments after merging \\
\hline The Tertiary & Services to household, education, health services & Life consumption \\
Industry & $\begin{array}{l}\text { and social welfare institutions culture, sports and } \\
\text { entertainment services, and public utilities }\end{array}$ & \\
\cline { 2 - 3 } & Wholesale, retail and restaurants & Wholesale, retail, and \\
& & restaurants \\
\cline { 2 - 3 } & $\begin{array}{l}\text { Financial institutions, real estate, rent services, } \\
\text { research and scientific institutions, general tech- }\end{array}$ & Other services \\
& $\begin{array}{l}\text { nical services, water, environment and public fa- } \\
\text { cilities }\end{array}$ & \\
\cline { 2 - 3 } & Transport and storage, communications, Informa- & Transport, storage and com- \\
& tion transmission, computer service and software & munications \\
\cline { 2 - 3 } & Construction & Construction \\
\hline The Secondary & Telecommunication, special equipments & $\begin{array}{l}\text { Telecommunication and spe- } \\
\text { cial equipments }\end{array}$ \\
\cline { 2 - 3 } & Primary iron and steel manufacturing, Primary & $\begin{array}{l}\text { Iron and steel manufactur- } \\
\text { ing }\end{array}$ \\
\hline
\end{tabular}


Table 3 continued

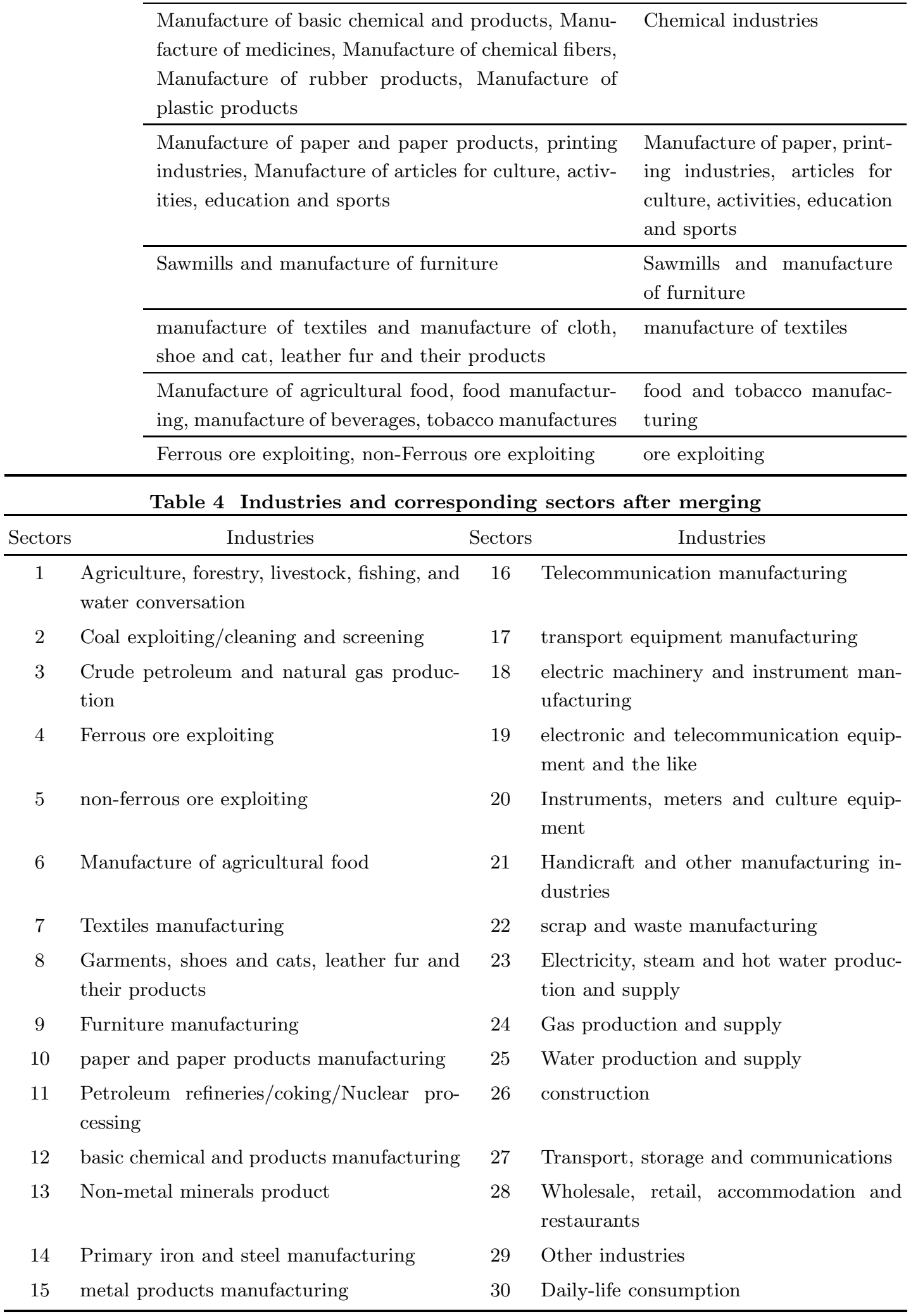




\section{Calculation results and empirical analysis}

\subsection{Comparisons of carbon emission coefficients among industries}

Based on the data of Input-Output Table and Energy Statistical Yearbook of China (2007), we obtain the thirty-sector's direct emission coefficients and total emission coefficients by using equations (1) and (2), as shown in Columns 2 and 4 of Table 5. It is found that TCEC is always

Table 5 Industries' carbon emission coefficients list

\begin{tabular}{cllllll}
\hline Sectors & $\begin{array}{l}\text { DCEC.(ton/ten } \\
\text { thousand }\end{array}$ & $\begin{array}{l}\text { Rank } \\
\text { by }\end{array}$ & $\begin{array}{l}\text { TCEC.(ton/ten } \\
\text { thousand }\end{array}$ & $\begin{array}{l}\text { Rank } \\
\text { by }\end{array}$ & $\begin{array}{l}\text { Percent change } \\
\text { from DCEC }\end{array}$ & $\begin{array}{l}\text { Rank by } \\
\text { percentage } \\
\text { change }\end{array}$ \\
\hline 1 & Yuan) & DCEC. & Yuan) & TCEC & TCEC & 18 \\
2 & 0.120567 & 18 & 0.379971 & 28 & 2.151541 & 30 \\
3 & 0.531577 & 3 & 1.052404 & 7 & 0.979778 & 23 \\
4 & 0.275766 & 11 & 0.675368 & 22 & 1.449058 & 17 \\
5 & 0.199269 & 13 & 0.767381 & 19 & 2.850974 & 16 \\
6 & 0.083287 & 21 & 0.462981 & 26 & 4.558845 & 11 \\
7 & 0.176146 & 15 & 0.792715 & 17 & 3.50033 & 13 \\
8 & 0.041604 & 26 & 0.598791 & 25 & 13.39265 & 6 \\
9 & 0.06352 & 23 & 0.62035 & 24 & 8.76617 & 9 \\
10 & 0.185484 & 14 & 0.792225 & 18 & 3.271125 & 14 \\
11 & 0.447042 & 6 & 1.068122 & 6 & 1.389313 & 24 \\
12 & 0.379048 & 9 & 1.182254 & 3 & 2.119008 & 19 \\
13 & 0.638198 & 2 & 1.377099 & 2 & 1.157792 & 26 \\
14 & 0.68416 & 1 & 1.610211 & 1 & 1.35356 & 25 \\
15 & 0.114383 & 19 & 1.088213 & 5 & 8.513723 & 10 \\
16 & 0.072931 & 22 & 0.893066 & 13 & 11.24544 & 7 \\
17 & 0.051534 & 24 & 0.807742 & 16 & 14.67391 & 5 \\
18 & 0.040639 & 27 & 0.978945 & 9 & 23.08891 & 1 \\
19 & 0.034839 & 29 & 0.672569 & 23 & 18.30514 & 3 \\
20 & 0.037964 & 28 & 0.71416 & 21 & 17.81156 & 4 \\
21 & 0.148637 & 16 & 0.822553 & 15 & 4.533956 & 12 \\
22 & 0.008098 & 30 & 0.0894 & 30 & 10.0392 & 8 \\
23 & 0.41953 & 7 & 1.135632 & 4 & 1.706911 & 21 \\
24 & 0.397666 & 8 & 0.996719 & 8 & 1.506424 & 22 \\
25 & 0.486277 & 4 & 0.9645 & 10 & 0.983437 & 29 \\
26 & 0.045957 & 25 & 0.921767 & 11 & 19.0573 & 2 \\
27 & 0.455122 & 5 & 0.906665 & 12 & 0.992135 & 28 \\
28 & 0.097666 & 20 & 0.380474 & 27 & 2.895674 & 15 \\
29 & 0.129084 & 17 & 0.377554 & 29 & 1.924869 & 20 \\
30 & 0.366237 & 10 & 0.766541 & 20 & 1.09302 & 27 \\
\hline$\overline{C E C}$ means "direct carbon emission coefficient"; TCEC refers "the total carbon emission coefficient". & \\
& & & & & & \\
\hline
\end{tabular}


greater than DCEC. The percent change from TCEC to DCEC is computed as in Column 6 of Table 5 .

We can draw the following conclusions from Table 5.

(A) There is a big difference between DCEC and TCEC for some sectors. From Columns two and four, on the one hand, the 18th sector of electrical machinery and equipment manufacturing industry ranks fourth from the bottom (27th) in DCEC (0.040639) and the ninth from the top (9th) in TCEC (23.08891), with TCEC (23.08891) being 24 times DCEC (0.040639). Thus, there is a biggest percent change from DCEC to TCEC for the 18th sector and ranks No.1 in "the embodied carbon emission" among the thirty sectors ${ }^{[18]}$.

(B) There is big difference in the types of industries between ranks by DCEC and TCEC. One group is featured by evident and stable carbon emission, including the black metal smelting and rolling processing (14th sector) and the nonmetal mineral products industry (13th sector). These two sectors rank No.1 and No.2, respectively, and are recognized as "main carbon emissioner" whether DCEC or TCEC is used to rank them. In addition, the oil processing and coking and nuclear fuel processing (11th sector), the black ore picking (4th sector) are also situated in the forefront of the sorting. However, the resource waste and recycled materials recovery processing (22th sector), the agricultural food processing (6th sector), the wood processing and wood, bamboo, cane, palm, grass industry (9th sector), and the textiles, garments, shoes, caps manufacturing (8th sector) with smaller DCEC and TCEC belong to typical relative low carbon industries.

(C) Seen from the fourth, sixth, and seventh column, these sectors are especially noteworthy for they are faced with a quite big difference between the direct coefficient and the complete coefficient, such as communications equipment, computer and other electronic equipment industry, wood processing and wood, bamboo, cane, palm, grassland manufacturing sector, and textiles, garments, shoes, caps manufacturing sector. Considering DCEC and TCEC together, their absolute coefficients rank in the last seven among the thirty departments. But the gap between DCEC and TCEC is the third, sixth and ninth respectively, which is explained by their numerous embodied carbon.

In conclusion, in order to implement energy conservation and emissions reduction, we should care about not only DCEC but also TCEC. We should keep a watchful eye on these sectors in the advanced position, such as black metal smelting and rolling processing, and those with absolute coefficients in the backward position but indirect emissions in the forefront, including communication equipment, computer and other electronic equipment industries. To strengthen the control of these industries is effective to achieve the purpose of energy conservation and emissions reduction.

\subsection{The results and analysis of complete carbon emissions}

Based on the economic data shown in Table 6, the calculation results are obtained (See Table 7).

From the Table 7 and the contribution proportion array (see Table 8) we learn the facts as follows. 
Table 6 Economic data

\begin{tabular}{|c|c|c|c|c|}
\hline Sectors & Final Consumption & Investment & Exports & Imports \\
\hline 1 & 114976729 & 20416358 & 6659785.1 & 23279609 \\
\hline 2 & 1477904.7 & 322179.29 & 2337578.2 & 1921708.1 \\
\hline 3 & 0.01 & 780969.97 & 1735647.8 & 57682693 \\
\hline 4 & 0.01 & 1339651.6 & 822875.31 & 40779994 \\
\hline 5 & 0.01 & 48479.645 & 1504403.3 & 3004363.7 \\
\hline 6 & 166879064 & 9481045.3 & 19121135 & 15815255 \\
\hline 7 & 4425356.6 & 1441898.8 & 82158911 & 8182909.9 \\
\hline 8 & 56712197 & 1083606.5 & 56726409 & 6087705.9 \\
\hline 9 & 5172106.4 & 12390713 & 24244658 & 2704832.5 \\
\hline 10 & 4212454.8 & 870725.56 & 22644209 & 8286283.2 \\
\hline 11 & 7459960.2 & -584369.5 & 7678378.3 & 14501469 \\
\hline 12 & 23510406 & 4922679 & 72379174 & 91051715 \\
\hline 13 & 2796629.3 & 541400.82 & 14836921 & 3772993.1 \\
\hline 14 & 0.01 & 6414101.4 & 51554905 & 43205060 \\
\hline 15 & 4108598.7 & 10923437 & 35585167 & 5846909.6 \\
\hline 16 & 648504.66 & 161909458 & 57368521 & 70433320 \\
\hline 17 & 24564891 & 102519414 & 32821566 & 30032045 \\
\hline 18 & 19230783 & 48783795 & 68256592 & 34351999 \\
\hline 19 & 19378979 & 44527208 & 213775082 & 162987370 \\
\hline 20 & 1797101.7 & 11395539 & 32373998 & 39298198 \\
\hline 21 & 13827573 & 8817384.6 & 13097173 & 2218830.8 \\
\hline 22 & 0.01 & 0.01 & 317293.34 & 14085868 \\
\hline 23 & 23529606 & 0.01 & 651130.47 & 179856.87 \\
\hline 24 & 3219925.1 & 52736.383 & 0.01 & 0.01 \\
\hline 25 & 3221088 & 0.01 & 0.01 & 0.01 \\
\hline 26 & 9318748.3 & 588465912 & 4088746.8 & 2212627.1 \\
\hline 27 & 40319079 & 2892475.9 & 40315450 & 11038922 \\
\hline 28 & 134956977 & 19848284 & 47440878 & 5233456 \\
\hline 29 & 166652305 & 37247554 & 33217686 & 31633541 \\
\hline 30 & 435232478 & 0.01 & 7230392.3 & 6386141.3 \\
\hline
\end{tabular}

In 2007, the gross carbon dioxide emission generated from China's domestic final demand for consumption, investment and exports add up to 2.53 billion tons. Among them, the total carbon of construction business (No.26) is up to 0.555 billions tons, occupying the first place with a percentage of $21.96 \%$. Therefore, to develop energy conservation building industry turns out to be one of the key direction towards energy saving and emission reduction. Besides, such industries as resource waste and recycled materials recovery processing (No.22), oil and 
natural gas exploiting (No.3), and non-metal ore picking (No.5) rank the first, the second, and the third from bottom respectively. Meanwhile, the carbon emission produced from exports demand reaches 0.78 billion tons with a proportion of $31.1 \%$ of the annual emissions in total.

Table 7 The Industries' complete-carbon-emission list

\begin{tabular}{|c|c|c|c|c|c|c|}
\hline Sectors & $\begin{array}{l}\text { Carbon } \\
\text { consumption }\end{array}$ & $\begin{array}{l}\text { Carbon } \\
\text { investment }\end{array}$ & $\begin{array}{l}\text { Carbon } \\
\text { exports }\end{array}$ & $\begin{array}{l}\text { Carbon } \\
\text { imports }\end{array}$ & $\begin{array}{l}\text { Net Carbon } \\
\text { exports }\end{array}$ & $\begin{array}{l}\text { Final } \\
\text { demand }\end{array}$ \\
\hline 1 & 43687804 & 7757620.6 & 2530524.1 & 8845572.5 & -6315048 & 53975949 \\
\hline 2 & 1555353.3 & 339062.9 & 2460077.5 & 2022414.1 & 437663.45 & 4354494 \\
\hline 3 & 0.0067537 & 527442.19 & 1172201.1 & 38957049 & -37784848 & 1699643 \\
\hline 4 & 0.0086508 & 1158912.2 & 711856.89 & 35278151 & -34566294 & 1870769 \\
\hline 5 & 0.0076738 & 37202.367 & 1154450.8 & 2305492.1 & -1151041 & 1191653 \\
\hline 6 & 77261802 & 4389541.9 & 8852718.5 & 7322159.2 & 1530559.3 & 90504062 \\
\hline 7 & 3508045.7 & 1143014.5 & 65128584 & 6486713.8 & 58641871 & 69779644 \\
\hline 8 & 33958727 & 648853.33 & 33967238 & 3645260.8 & 30321977 & 68574818 \\
\hline 9 & 3208516.3 & 7686579.4 & 15040174 & 1677942.9 & 13362231 & 25935270 \\
\hline 10 & 3337210.7 & 689810.28 & 17939302 & 6564598.1 & 11374704 & 21966323 \\
\hline 11 & 7968150.1 & -624178.1 & 8201447.3 & 15489343 & -7287896 & 15545419 \\
\hline 12 & 27795266 & 5819855.9 & 85570552 & 107646234 & -22075682 & $1.19 \mathrm{E}+08$ \\
\hline 13 & 3851235.4 & 745562.52 & 20431909 & 5195785 & 15236124 & 25028707 \\
\hline 14 & 0.0161021 & 10328059 & 83014296 & 69569280 & 13445016 & 93342355 \\
\hline 15 & 4471028.7 & 11887021 & 38724226 & 6362680.4 & 32361545 & 55082276 \\
\hline 16 & 579157.7 & 144595892 & 51233897 & 62901629 & -11667733 & $1.96 \mathrm{E}+08$ \\
\hline 17 & 19842105 & 82809282 & 26511372 & 24258158 & 2253214.3 & $1.29 \mathrm{E}+08$ \\
\hline 18 & 18825870 & 47756629 & 66819417 & 33628702 & 33190715 & $1.33 \mathrm{E}+08$ \\
\hline 19 & 13033700 & 29947619 & 143778490 & 109620250 & 34158240 & $1.87 \mathrm{E}+08$ \\
\hline 20 & 1283419 & 8138242.8 & 23120228 & 28065218 & -4944990 & 32541890 \\
\hline 21 & 11373907 & 7252763.1 & 10773115 & 1825105.1 & 8948009.3 & 29399785 \\
\hline 22 & 0.000894 & 0.000894 & 28366.06 & 1259278.2 & -1230912 & 28366.06 \\
\hline 23 & 26720962 & 0.0113563 & 739444.29 & 204251.13 & 535193.16 & 27460406 \\
\hline 24 & 3209359.2 & 52563.333 & 0.0099672 & 0.0099672 & 0 & 3261923 \\
\hline 25 & 3106739.6 & 0.009645 & 0.009645 & 0.009645 & 0 & 3106740 \\
\hline 26 & 8589712.3 & 542428307 & 3768870.9 & 2039526.1 & 1729344.8 & $5.55 \mathrm{E}+08$ \\
\hline 27 & 36555893 & 2622506.3 & 36552603 & 10008603 & 26544000 & 75731002 \\
\hline 28 & 51347604 & 7551753.5 & 18050015 & 1991193.3 & 16058822 & 76949373 \\
\hline 29 & 62920163 & 14062945 & 12541454 & 11943354 & 598099.7 & 89524562 \\
\hline 30 & 333623484 & 0.0076654 & 5542391.2 & 4895238.3 & 647152.89 & $3.39 \mathrm{E}+08$ \\
\hline total & 801615217 & 939752862 & 784359219 & 610009182 & 174350037 & $2.53 \mathrm{E}+09$ \\
\hline
\end{tabular}


Table 8 Contribution proportion array

\begin{tabular}{|c|c|c|c|c|c|c|}
\hline \multirow{2}{*}{ Sectors } & \multicolumn{6}{|c|}{ Unit: percentage } \\
\hline & $\begin{array}{l}\text { Carbon } \\
\text { consumption }\end{array}$ & $\begin{array}{l}\text { Carbon } \\
\text { investment }\end{array}$ & $\begin{array}{l}\text { Carbon } \\
\text { exports }\end{array}$ & $\begin{array}{l}\text { Carbon } \\
\text { imports }\end{array}$ & $\begin{array}{l}\text { Net Carbon } \\
\text { exports }\end{array}$ & $\begin{array}{l}\text { Final } \\
\text { demand }\end{array}$ \\
\hline 1 & 0.054499719 & 0.008255 & 0.003226 & 0.014501 & -0.03622 & 0.02137 \\
\hline 2 & 0.001940274 & 0.000361 & 0.003136 & 0.003315 & 0.00251 & 0.001724 \\
\hline 3 & $8.42511 \mathrm{E}-12$ & 0.000561 & 0.001494 & 0.063863 & -0.21672 & 0.000673 \\
\hline 4 & $1.07917 \mathrm{E}-11$ & 0.001233 & 0.000908 & 0.057832 & -0.19826 & 0.000741 \\
\hline 5 & $9.57292 \mathrm{E}-12$ & $3.96 \mathrm{E}-05$ & 0.001472 & 0.003779 & -0.0066 & 0.000472 \\
\hline 6 & 0.096382654 & 0.004671 & 0.011287 & 0.012003 & 0.008779 & 0.035833 \\
\hline 7 & 0.004376221 & 0.001216 & 0.083034 & 0.010634 & 0.336346 & 0.027628 \\
\hline 8 & 0.042362877 & 0.00069 & 0.043306 & 0.005976 & 0.173914 & 0.027151 \\
\hline 9 & 0.004002564 & 0.008179 & 0.019175 & 0.002751 & 0.07664 & 0.010268 \\
\hline 10 & 0.004163108 & 0.000734 & 0.022871 & 0.010761 & 0.065241 & 0.008697 \\
\hline 11 & 0.009940118 & -0.00066 & 0.010456 & 0.025392 & -0.0418 & 0.006155 \\
\hline 12 & 0.034674075 & 0.006193 & 0.109096 & 0.176467 & -0.12662 & 0.047189 \\
\hline 13 & 0.004804344 & 0.000793 & 0.026049 & 0.008518 & 0.087388 & 0.00991 \\
\hline 14 & $2.00871 \mathrm{E}-11$ & 0.01099 & 0.105837 & 0.114046 & 0.077115 & 0.036957 \\
\hline 15 & 0.005577525 & 0.012649 & 0.049371 & 0.01043 & 0.185612 & 0.021808 \\
\hline 16 & 0.000722488 & 0.153866 & 0.065319 & 0.103116 & -0.06692 & 0.077763 \\
\hline 17 & 0.024752655 & 0.088118 & 0.0338 & 0.039767 & 0.012924 & 0.051139 \\
\hline 18 & 0.023484921 & 0.050818 & 0.08519 & 0.055128 & 0.190368 & 0.052817 \\
\hline 19 & 0.016259297 & 0.031868 & 0.183307 & 0.179703 & 0.195918 & 0.073943 \\
\hline 20 & 0.001601041 & 0.00866 & 0.029477 & 0.046008 & -0.02836 & 0.012884 \\
\hline 21 & 0.014188736 & 0.007718 & 0.013735 & 0.002992 & 0.051322 & 0.01164 \\
\hline 22 & $1.11525 \mathrm{E}-12$ & $9.51 \mathrm{E}-13$ & $3.62 \mathrm{E}-05$ & 0.002064 & -0.00706 & $1.12 \mathrm{E}-05$ \\
\hline 23 & 0.033333901 & $1.21 \mathrm{E}-11$ & 0.000943 & 0.000335 & 0.00307 & 0.010872 \\
\hline 24 & 0.004003616 & $5.59 \mathrm{E}-05$ & $1.27 \mathrm{E}-11$ & $1.63 \mathrm{E}-11$ & 0 & 0.001291 \\
\hline 25 & 0.0038756 & $1.03 \mathrm{E}-11$ & $1.23 \mathrm{E}-11$ & $1.58 \mathrm{E}-11$ & 0 & 0.00123 \\
\hline 26 & 0.010715506 & 0.577203 & 0.004805 & 0.003343 & 0.009919 & 0.219654 \\
\hline 27 & 0.045602793 & 0.002791 & 0.046602 & 0.016407 & 0.152245 & 0.029984 \\
\hline 28 & 0.064055176 & 0.008036 & 0.023012 & 0.003264 & 0.092107 & 0.030466 \\
\hline 29 & 0.078491727 & 0.014965 & 0.015989 & 0.019579 & 0.00343 & 0.035445 \\
\hline 30 & 0.41618906 & $8.16 \mathrm{E}-12$ & 0.007066 & 0.008025 & 0.003712 & 0.134284 \\
\hline
\end{tabular}

In detail, the sectors including communications equipment, computer and other electronic equipment industry (No.19) are recognized as No.1 due to their highest ratio of $18.3 \%$, equal to 0.144 billion tons. However, those that provide consuming products involving gas production and supply (No.24), water production and supply (No.25) follow in the rear. 
Furthermore, the emission-reduction volume of imports is 0.61 billion tons with a percentage of $24.2 \%$. And the industries of communication equipment, computer and other electronic equipment manufacturing (No.19), chemical raw materials and chemical products manufacturing (No.12) ranks the first and the second separately while both gas production and supply (No.24) and water production and supply (No.25) are the last and the last but one in the ranking.

As to net export carbon emission, it is up to 0.17 billion tons arising from global trade which makes China a carbon pollution inputting nation. The textiles industry achieved a biggest contribution ratio of $33.6 \%$, which further emphasizes the face that China's exporting structure is still confined to a majority of industries with low value-added.

As far as consuming demand is mentioned, the carbon emission volume reaches 0.82 billion tons, of which consumer goods sector (No.30) with 0.33 billion tons accounting for $41.6 \%$ is far ahead of agricultural food processing sector situated in the second place with a percentage of $9.6 \%$ only. On the other hand, the resource waste and recycled materials recovery processing (No.22), oil and natural gas exploiting industry (No.3), and nonmetal ore picking (No.5) are in no doubt among the bottom three. Consider investment demand, the carbon emission produces 9.39 million tons of volume, where construction sector (No.26) ranks No.1 with the highest proportion of $57.7 \%$ equaling 5.42 billion tons, and oil processing and coking and nuclear fuel processing (No.11) are shown as negative values for they adopts inventory investment instead of zero investment demand, and the resource waste and recycled materials recovery processing (No.22) sector should bring up the rear.

As for the above empirical results, we make some analysis of each industry in question from their actual development status.

The construction industry in China takes up $10 \%$ of the newly increased building output annually in the world. A majority of the buildings are dependent on high volume of carbon and energy consumption resulting from such bottlenecks as mass production, inferior quality, short life, unnecessarily big house type, old-fashioned design, and less strategic support from governments. The most influential determinant lies in the fact that some buildings at home only live 50-to-60 year or even 10-to-20 year prior to demolition or reconstruction, falling far behind developed countries who have witnessed their building ranging from 100 to 150 years ${ }^{[19]}$. Additionally, the construction industry has made excessive use of high-emission cement as one of raw materials. And as to the cement manufacturing sector, approximately two thirds of cement output stem from limestone's chemical decomposition, which is exemplified by the 1.06billion-ton cement accompanied by 0.39 billion tons of $\mathrm{CO}_{2}$ in 2005 and 1.65-billion-ton cement with $\mathrm{CO}_{2}$ emission of 0.56 billion tons in $2009^{[20]}$. All in all, it is well advised to pay great attention to the construction industry that generates the largest amount of carbon emission among all the industries and sectors in China.

Communication equipment, computer and other electronic equipment industry, in accordance with carbon emissions coefficients mentioned above, is perceived as a foreign-tradeoriented sector featured by most significant carbon intensity, which is closely connected with its internal attributes of high-tech and high-energy-consumption. In other words, it has consumed enormous energy with constant expansion of internet scale and growth of telecommunications 
webs that are triggered by increasingly-developed network, power system and computer room, base-station, etc. Up to now, China has possessed almost a thousand lord exchange equipment sets and several-hundred thousand base stations that constitute an uninterrupted network environment, which actually requires a considerable amount of energy. For instance, the base stations annually consume power reaching to 7 billion degree on average by using air conditioners. And the total sum of electricity consumption in 2009 is more than 20 billion degree for the telecommunications industry as a whole ${ }^{[21]}$.

Concerning daily living consumption sectors, with the rapid and sustainable growth of our economy, the living standards of urban and rural residents has improved a lot and the energy consumed in daily life have soared remarkably, especially during the recent 20 years the total living consumption has risen from 9583 thousand tons in 1980 to 26789.7 thousand tons in 2007 with an annual average growth rate of $3.74 \%^{[22]}$. It is the household electronic appliances and cars that lead to higher energy consumption and more carbon emission. For example, average car ownership for a urban family has increased from 0.34 units per one-hundred family in 1999 to 6.06 units in 2007, while for rural residents, average ownership of refrigerators per one-hundred family has reached from 1.22 sets in 1990 to 26.12 sets in $2007^{[23]}$. Furthermore, considering rural residents rigid demand for energy and the approaching stage of well-off society, Chinese residents and those living in rural areas in particular are sure to suffer from higher pressure related to living energy and carbon emission.

\section{Conclusion and suggestions}

This article makes use of the latest input-output data of 2007 to obtain the results of complete carbon emissions of different industries that partial industries belong to obvious highcarbon industry, whether from the direct coefficient or complete coefficient, such as black metal smelting and rolling processing, nonmetal mineral products industry; some belong to highcarbon intensity industry, such as electrical machinery and equipment manufacturing construction, and the direct coefficient is bigger than the complete coefficient; other sectors are especially noteworthy which is big different between the direct coefficient and the complete coefficient, such as communications equipment, computer and other electronic equipment industry. From the perspective of total amounts, construction is the first industry to satisfy domestic demand, and communication equipment, computer and other electronic equipment industry is the most significant of trade departments.

We attempt to raise some useful suggestions with respect to energy conservation and emission reduction as follows.

1) Promoting innovation of technical standard system in order to guide industries in energy saving. As for the construction industry, it is strongly recommended to draw up a housing industrialization technical system and to tailor industrialization measure including "building blocks" type housing, which is surely to reduce energy consumption arising during building construction and at the same time to cut down building rubble and thus protect the environment effectively. We are also required to implement mandatory new-energy-application policy with the purpose of improving awareness of benefits from energy reduction projects. Besides, it is an effective approach to solve shortage of talents needed in this brand new area by cooperating 
with colleges and universities and with social certificate training organization related. Furthermore, it is necessary to formulate technical criteria for products and/or services involved in telecommunications industry, accompanied by such means as monitoring goods energy-saving index and controlling energy consumption generated by telecommunications equipments and generator rooms in particular. Finally, it is needed to work out a guideline of cleaner production for staffs in relevant industries and certain special projects plans on key energy-saving technologies promotion.

2) Pushing innovation of energy-saving-oriented economic management in order to idealize the strategic carbon-emission-reduction system covering finance, revenue, banking and pricesetting. To start with, financial strategies are required to target low-carbon techniques and call for more investment in this area by establishing stated-owned engineering centers and laboratories specializing in energy saving, resources utilization and environment protection. In addition, experts and technicians should be encouraged to tackle key problems of high efficient generation of power, cleaner production in seriously-polluted industries, and emission reduction in the field of construction industry, and to develop a series of technologies that are able to be applied universally in almost every industry or sector. Then as for banking and revenue strategies, they should pay more attention to energy-saving-oriented manufacturers together with relevant projects by encouraging banks to provide them with financial aid. The advisable specific measures include allowing them to apply for mortgage loan that will be invested in energy conservation projects, agreeing to reduce or even cancel taxes on energy-management contracts, stimulating energy management companies to set foot in public infrastructure such as municipal lighting and large-scale public property, etc., and further boosting price reforms in terms of resource products, oil tax, natural gas, industrial electricity, residents electricity, water and so on.

\section{References}

[1] Lin B Q, Yao X, Liu X Y. Strategy adjustment of China's energy structure under the restriction of energysaving and carbon emissions. China Social Sciences, 2010, 1: 58-71.

[2] Nobuko Y. An analysis of $\mathrm{CO}_{2}$ emissions of Japanese industries during the period between 1985 and 1995 . Energy Policy, 2004, 32: 595-610.

[3] Mauricio T T, Giovanni M. Energy and carbon embodied in the international trade of Brazil. Mitigation and Adaptation Strategies for Global Change, 2003, 8(2): 139-155.

[4] Giovani M, Roberto S, Ernst W. Energy and carbon embodied in the international trade of Brazil: An input-output approach. Ecological Economics, 2001, 39(3): 409-424.

[5] Julio S, Rosa D. $\mathrm{CO}_{2}$ emissions embodied in international trade: Evidence for Spain. Energy Policy, 2004, 32(18): 1999-2005.

[6] Manfred L. Primary energy and greenhouse gases embodied in Australian final consumption: An inputoutput analysis. Energy Policy, 1998, 26(6): 495-506.

[7] Mongelli I, Tassielli G, Notarnicola B. Global warning agreement, international trade and energy/carbon embodiments: An input-output approach to the Italian case. Energy Policy, 2006, 35(1): 88-100.

[8] Kakali M. Impact of liberalized trade on energy use and environment in India. Env Ecol Manag, 2004, 1(1): 75-104.

[9] Chen H M. Analysis on embodied $\mathrm{CO}_{2}$ emissions including industrial process emissions. Chinese Population Resource and Environment, 2009, 3: 25-30.

[10] Wei B Y, Fang X Q, Wang Y, et al. Estimation of carbon emissions embodied international trade for China: An input-ouput analysis. Journal of Beijing Normal University (Natural Science), 2009(4): 413-419. 
[11] Wei B Y. Estimation of carbon emissions embodied in export in the view of final demands for China. Scientia Geographica Sinica, 2009, 10(5): 634-640.

[12] Qi Y. Estimate of implicit carbon of China's import and export. Chinese Population, Resource and Environment, 2008, 3: 8-13.

[13] Bin S, Robert C H. The role of $\mathrm{CO}_{2}$ embodiment in US-China trade. Energy Policy, 2006, 34: 4063-4068.

[14] Liu H G. The origin source and its elasticity analysis of the $\mathrm{CO}_{2}$ emission induced by fossil fuel using industrial activities in China. Progress in Geography, 2010, 6: 670-676.

[15] Li X P, Lu X X. International trade, pollution industry transfer and Chinese Industries' $\mathrm{CO}_{2}$ emissions. Economy Research, 2010, 1: 15-26.

[16] Industrial Traffic Statistical Departments of National Bureau. Statistics of China's Energy Yearbook (2007). China Statistical Publishing House, 2008.

[17] Xu Y G, Wu Z X. International carbon transfer: International trade and investment. The World Environment, 1998, 1: 86-92.

[18] Kahrl F, Roland-Holst D. Energy and exports in China. China Economic Review, 2008, 19(4): 649-658.

[19] Yu H C, Wang L M. Research on the carbon emission transfer by Sino-US merchandise trade. Journal of Natural Resources, 2009, 10: 1837-1846.

[20] He Z X. Four opinions about energy conservation and emissions reduction of construction. Architecture, 2010, 15: 19-33.

[21] Zhou X. Emissions embodied in international trade and trade adjustment to national GHG inventory. Management Review, 2010, 22(6): 17-24.

[22] Robert A H, Clark W B. The energy cost of goods and services. Energy Policy, 1975, 3(4): 268-278.

[23] Fan J L, Liao H, Liang Q M, et al. Study on characteristics of residents' life energy in our country. China Energy, 2010, 8: 53-56. 